This is a post-print (ie final draft post-refereeing) version of the article.

The article has been published as T Schonwetter \& CB Ncube 'New hope for Africa? Copyright and Access to Knowledge in the Digital Age' (2011)

13(3) Info 64 -74 http://dx.doi.org/10.1108/14636691111131457

It is archived here in accordance with the Journal's copyright and self-archiving policy - see annexure

\title{
New hope for Africa? Copyright and access to knowledge in the digital age
}

Dr. Tobias Schonwetter ${ }^{1}$, University of Cape Town, tobias.schonwetter@uct.ac.za Caroline B Ncube ${ }^{2}$, University of Cape Town, caroline.ncube@uct.ac.za

\section{$\underline{\text { Abstract }}$}

For African countries, accessing knowledge material is crucial to unlock sustainable development. $^{3}$ While information and communication technologies (ICTs) facilitate access to such material, an access-enabling national copyright regime is equally important: Applied wisely, copyright law has the potential to promote learning through ICTs, but applied too strictly, copyright law has the potential to restrict access to knowledge. Digital technologies and the Internet have intensified copyright disputes because copyright infringement is a greater threat in the digital age than it was before. At the same time, digital technologies allow for the lock-up of copyrightprotected material by way of technological protection measures (TPMs), regardless of established copyright balancing tools that strive to reconcile rights holders interests and public interests. Copyright exceptions and limitations are the most important legislative balancing tool that can be severely affected by TPMs.

This paper discusses the three main approaches countries around the world have taken towards copyright exceptions and limitations. After examining the advantages and disadvantages of the different approaches, it suggests a preferred model for developing countries. It then addresses the problematic interplay between copyright exceptions and limitations on the one hand and TPMs on the other. The paper concludes by offering a solution for mitigating the potentially detrimental impact of TPMs on otherwise-permitted uses of copyright-protected knowledge materials.

\footnotetext{
1. Tobias Schonwetter is a postdoctoral fellow at the University of Cape Town's Intellectual Property Research Unit, Department of Private Law.

2. Caroline B Ncube is a lecturer at the University of Cape Town's Law Faculty, Department of Commercial Law and is a member of the Intellectual Property Research Unit..

3. The link between the accessibility and flow of information on the one hand and power and development on the other has been addressed by many authors. See, for instance, P Drahos and R Mayne Global Intellectual Property Rights: Knowledge, Access and Development (2002).
} 


\section{$\underline{\text { Introduction }}$}

For African countries, accessing knowledge material is crucial to unlock sustainable development. Information and communication technologies (ICTs) facilitate access to information. However, any network infrastructure for accessing online information needs to be supported by an enabling legal environment. In particular, access-enabling national copyright regimes are imperative. This is because most information and knowledge materials are copyright-protected. And while ICTs have the potential to significantly improve the general availability of knowledge material, it is yet another question whether such material is indeed accessible. Applied wisely, copyright law has the potential to facilitate learning through ICTs, but applied too strictly, copyright law has the potential to restrict access to knowledge.

Some of the characteristics of digital technologies have the potential to disrupt the traditional balance of interests in the copyright arena. On the one hand, they make possible large-scale infringement of copyright-protected material. On the other hand, they allow for the lock-up of copyright-protected material by way of technological protection measures (TPMs), regardless of established copyright balancing tools such as copyright exceptions and limitations that allow various permission-free uses to promote the public interest and to respect users' legitimate interests in using copyright-protected materials.

The authors of this paper have, as country researchers for the African Copyright and Access to Knowledge (ACA2K) project (www.aca2k.org), examined the relationship between copyright protection and access to knowledge, particularly in relation to learning materials, in selected African countries from a development perspective. ${ }^{4}$ ACA2K research was premised on the basis that 'Access to knowledge is essential for economic development, cultural realisation and individual fulfilment' and that it is so critical to human development that it is rapidly emerging as a basic human right'. ${ }^{5}$

\footnotetext{
${ }^{4}$ ACA2K Project Methodology Guide (2008) available at www.aca2k.org. For the research outcomes see aca2k.org for the eight country reports and Tobias Schonwetter, Jeremy de Beer, Dick Kawooya \& Achal Prabhala 'Copyright and education:Lessons on African copyright and access to knowledge' (2009/2010) African Journal of Information and Communication 37.

${ }^{5}$ ACA2K Project Methodology Guide (supra) at 7. See also Commission on Intellectual Property Rights
} 
Among other things, ACA2K research indicates that while copyright limitations and exceptions are particularly important for access to learning materials, existing copyright limitations and exceptions in all eight study countries are generally inadequate for sufficient knowledge materials access. Of particular concern, however, are anti-circumvention provisions in the laws of some African countries. Anti-circumvention provisions are clauses that make it illegal to circumvent TPMs. The effect of such provisions is that users seeking to exercise their rights under existing copyright exceptions and limitations - including fair dealing and fair use could be prevented from exercising these rights where the copyright-protected item in question is protected by TPMs.

The purpose of this paper is twofold. First, it aims at deepening the general understanding regarding copyright exceptions and limitations as an important balancing tool of copyright law. It is the lack of understanding and, as a result, the use of wrong terminology that cause confusion as to the scope of copyright exceptions and limitations. For instance, users of copyright-protected material in South Africa commonly refer to their "fair use" rights although such rights are unknown in our copyright law. For this reason, this paper explains the three main approaches countries around the world have taken towards copyright exceptions and limitations to enable knowledge materials access. In particular, the differences between the often-confused fair use approach and fair dealing provisions are explained. The paper then examines the advantages and disadvantages of the different approaches and suggests a preferred model for developing countries.

(CIPR) (2002) Integrating Intellectual Property Rights and Development Policy: Report of the Commission on Intellectual Property Rights, London, September, http://www.iprcommission.org/graphic/documents/final report.htm, Consumers International Asia Pacific (2006) Copyright and Access to Knowledge: Policy Recommendations on Flexibilities in Copyright Laws, Kuala Lumpur, http://www.soros.org/initiatives/information/focus/access/articles publications/publications/copyrig ht 20060602/copyright access.pdf, Rens, A, Prabhala, A \& Kawooya, D (2006) Intellectual Property, Education and Access to Knowledge in Southern Africa, Tralac Working Paper No, 13, ICTSD, UNCTAD and TRALAC, http://www.tralac.org/pdf/20061002 Rens IntellectualProperty.pdf, Kawooya, D (2006) Copyright and Access to e-Resources in Africa's Education and Research Contexts: The Case of Selected Ugandan Institutions, http://www.policy.hu/kawooya/documents/Kawooya IPF Study2006Final.pdf. 
In its second part, the paper describes the problematic interplay between copyright exceptions and limitations on the one hand and TPMs - and their legal protection on the other. While the authors do not intend to provide an in-depth legal analysis of this topic, it appears crucial to point to and raise awareness about the relationship between TPMs and copyright exceptions and limitations in order to improve the current situation in South Africa. The paper concludes by offering a solution for mitigating the potentially detrimental impact of TPMs on otherwise-permitted uses of copyright-protected knowledge materials.

While socio-legal research encompasses many different methodological and disciplinary fields, this paper follows a predominantly legal methodology that aims at advancing the understanding, application and interpretation of the law and addresses legal the legal problems at hand.

\section{The three main approaches towards copyright exceptions and limitations}

Limitations and exceptions curtail the exclusive rights assigned by copyright law to the copyright-holder. They do this to promote the public interest and to respect users' legitimate interests in using copyright-protected material in certain circumstances without the permission of the rights-holder. If copyright law is described as the legal environment in which a fair and optimal balance ought to be struck between the competing interests, it is by means of copyright limitations and exceptions that this objective is best achieved.

National legislators are, however, not free to introduce copyright exceptions and limitations into their own domestic laws. They are bound by the international treaties and agreements dealing with copyright protection. Most of the relevant international bilateral, regional and multilateral treaties to which a country is a party influence and - after all - considerably restrict the scope of copyright exceptions and limitations. Of particular importance is the so-called three-step test. The three-step 
test appears in the Berne Convention (Article $9(2))^{6}$, TRIPS (Article 13), ${ }^{7}$ the WCT $\left(\right.$ Article 10) ${ }^{8}$ and the WPPT (Article 16). ${ }^{9}$ In addition, several European Directives ${ }^{10}$ as well as numerous Free Trade Agreements ${ }^{11}$ and national copyright laws ${ }^{12}$ contain the test.

In essence, the three-step test determines the circumstances under which domestic legislation can limit the exclusive rights of the rights holders. More precisely, the test allows exceptions and limitations to exclusive rights only

a) in certain special cases;

b) that do not conflict with the normal exploitation of the work; and

c) do not unreasonably prejudice the legitimate interests of the author/ rights holder.

While the precise meaning of each of the steps remains disputed, the test can perhaps best be summarised and clarified as follows: Copyright exceptions and limitations are permissible if they (1) are not unduly vague, (2) do not deprive the rights holders of tangible income in areas in which rights holders normally obtain such income from copyright, and (3) do not harm the interests of the rights holders in a disproportional way.

\footnotetext{
6 . Berne Convention for the protection of literary and artistic works 1161 UNTS 3.

7. Agreement on trade-related aspects of intellectual property rights including trade in counterfeit goods, Marrakesh Agreement Establishing the World Trade Organisation, Annex 1C, 33 ILM 1125, 1197 (hereafter TRIPS or TRIPS Agreement).

8 . WIPO Copyright Treaty 36 ILM 65 (WCT).

9. WIPO Performances and Phonograms Treaty 36 ILM 76.

10. See Article 5(5) of the EU Copyright Directive (2001/29/EC), Article 6(3) of the Computer Programs Directive (91/250/EEC), Article 6(3) of the EC Database Directive (96/9/EC) and Article 10(3) of the EC Rental Right Directive (2006/115/EC).

11. See, for example, Article 17.4(10)(a) of the Australia-U.S. Free Trade Agreement (AUSFTA); Article 1705(5) of the North American Free Trade Agreement (NAFTA) and Article 16.4(10) of the U.S.-Singapore Free Trade Agreement.

12. See, for instance, section 13 of the South African Copyright Act No 98 of 1978 as amended and section 200AB(1) of the Australian Copyright Act 1968 as amended. The three-step test was also introduced in France (Art.L. 122-5 as well as Art 211-3 and Art 342-3 IPC), Italy (Art 71nonies and Art 71sexies(4) of the Italian Copyright Statute), Greece (Art 28(c) of the Greek Copyright Act), Portugal (Art 75(4) of the Portuguese Act on Copyright), Spain (Art 40bis of the Spanish Copyright Act). China introduced the second and the third steps into its law (Art 21).
} 
Apart from the requirements contained in the three-step test, the scope of national copyright exceptions and limitations is influenced by the philosophical foundation on which copyright protection rests domestically. As a general rule, limitations and exceptions in natural law based copyright regimes are usually less far-reaching or broad than exceptions and limitations in countries and regions with a utilitarian tradition of copyright protection. This is because the author-centric natural law approach results in a more reserved stance towards unauthorised uses of copyrightprotected works than the utilitarian copyright rationale which focuses on public benefit considerations.

Lastly, developmental considerations play a significant role when it comes to a country's approach to copyright exceptions and limitations. In a developing country like South Africa for instance, where educational deficiencies are a main cause for many of the most pressing socio-economic problems, copyright exceptions and limitations are a crucial national policy tool to overcome developmental shortfalls. For it is by way of such exceptions and limitations that access to educational material can be facilitated since copyright protection would otherwise bar considerable amounts of knowledge material from being reproduced and disseminated freely.

Given the crucial importance of copyright exceptions and limitations as a legislative tool for realising national public policy considerations - such as the enforcement of developmental targets, the stimulation of domestic creativity, the dissemination of knowledge, the access to educational material, and the promotion of welfare as a whole - it is appropriate to look at how different countries have dealt with the often vague international requirements in their domestic legislation.

In general, it is convenient to distinguish three main approaches to copyright exceptions and limitations in national copyright laws: First, some countries, especially civil law countries in continental Europe, follow a specific provisions approach and incorporate rather long lists of specifically phrased copyright exceptions and limitations into their copyright laws. Secondly, some countries, most 
notably the U.S., have chosen to introduce into their copyright laws broad, openended so-called fair use provisions. These provisions are usually accompanied by only a few more specific copyright exceptions and limitations. Thirdly, there are countries, especially those in the common law tradition, that have opted for a compromise. While their copyright laws contain, specific copyright exceptions and limitations, they also employ broader so-called fair dealing provisions. According to these fair dealing provisions, the unauthorised use of protected works is permitted if the use can be considered fair in light of the underlying purpose. Such underlying purposes are research, (private) study, criticism and review, news reporting, teaching, use by disabled persons and use by archives as well as libraries. ${ }^{13}$

The concepts of fair use in the U.S. and fair dealing in other countries must not be confused. Both concepts share the same fundamental idea of permitting uses which are considered fair. However, the concept of fair use is, in general, much broader than the concept of fair dealing because it is not confined to specific purposes such as research, study, criticism and review or news reporting. Furthermore, some of the uses permitted under the concept of fair dealing only pertain to certain kinds of protected works ${ }^{14}$. Therefore, fair use and fair dealing are analogous rather than synonymous. In a way, the concepts may even be described as converse: Under the fair dealing concept permitted uses are regulated by law and the courts are required to develop certain general principles from those kinds of uses. By contrast, under the fair use doctrine the principles for permitted uses are specified, and it is left to the courts to determine certain kinds of uses. ${ }^{15}$

It is suggested here that the international three-step test allows both the relatively broad general clause exceptions and limitations (including fair dealing clauses) and

\footnotetext{
13. D Gervais 'Towards a new core international copyright norm: The reverse three-step test' (2005) 9 Marquette Intellectual Property Law Review 1 at 21.

14. For instance. section 29 of the UK CDPA only applies to literary (including computer programs), dramatic, musical or artistic works.

15. The difference between both concepts has also been described as follows (H Laddie et al The modern law of copyright and designs [3ed] (2000) para 3.134):

Fair use should be distinguished from the statutory defences based on fair dealing; the latter are conceptually distinct since they pre-suppose that a substantial part has been taken.
} 
the more specific lists of copyright exceptions and limitations. Having said this, it appears the test favours the specific provisions approach: A general clause exception or limitation is more likely to violate the requirements contained in the first step of the three-step test. One could even argue that existing broad fair use exceptions, particularly in the U.S., only pass the three-step test because their lack of definiteness is compensated by rich bodies of case law. Any country considering the introduction of a fair use provision should take into account that such clarifying domestic case law does in their country naturally not exist.

At first glance, however, a more flexible approach is nonetheless attractive for national lawmakers. Legal flexibility is crucial in times where rapid technological developments facilitate new uses which could not be anticipated when the law was drafted. Yet flexibility, particularly the high level of flexibility offered by the fair use doctrine, comes at a high price. The vagueness of open-ended fair use provisions results in a legal uncertainty which is hardly tolerable. Vagueness obviously allows different interpretations, and if a provision can be interpreted in two or more ways, it is almost inevitable that it will involve the courts in deciding cases concerning fair use. While this may be intended to attain fair decisions on a case-by-case basis, it can safely be assumed that nowadays at least some users will shy away from timeconsuming and costly litigation and not be willing to test the limits of fair use. This will mean that a doctrine designed to allow the use of copyright material actually prevents uses in numerous cases. It is, therefore, problematic to make such a doctrine a country's legislative backbone for copyright exceptions and limitations.

Inflexible specific provisions appear, however, to be an equally poor alternative. It became obvious in recent years that, in times of rapid technological developments, fixed lists of copyright exceptions and limitations are often inappropriate. For example, even in developed countries numerous now-popular activities such as time-shifting, space-shifting and reverse-engineering were, if at all, only addressed with considerable delay because legislative amendment procedures could not keep up with the pace of development. This is likely to be even truer in developing 
countries. As a result, everyday activities such as the copying of music from legitimately purchased CDs onto a portable MP3 player remain, in principle, illegal in many countries.

The following solution is suggested here. It combines the advantages of both approaches while, at the same time, minimising the described disadvantages: in order to achieve the highest degree possible in respect of legal certainty, developing countries should strive to include as many (inflexible) specific copyright exceptions and limitations as possible into their respective copyright laws. The extensive list of copyright exceptions and limitations contained in Article 5 of the EU Copyright Directive provides a helpful starting point in this respect. In certain areas, however, for example, for study and research purposes, more flexible fair dealing provisions may be of use. In addition, a fair use provision should be included as a subordinate catchall clause which only applies if no other copyright exception and limitation is available. The main application of this provision would be in areas where lawmakers have not yet been able to adjust the law to changed circumstances and technological realities, for instance by way of introducing new or amending existing copyright exceptions and limitations. Wherever possible, the adoption of clarifying, nonbinding guidelines is advised in order to improve legal clarity and to minimise the aforementioned conflict with the three-step test. Often, the interpretation of such guidelines falls on collecting societies and large-scale commercial users such as broadcasters or radio stations or university consortiums; and there will surely be a need for these stakeholders to provide such clarifications in the future. Having said this, future guidelines should ideally be formulated in a manner that is more intelligible to all in order to not simply provide an interpretation tool that itself requires interpretation and thus merely shifts the conflict among stakeholders from one level (the interpretation of the law) to another (the interpretation of guidelines). The decisive advantage of guidelines, generally, is that they can be updated easier and faster than legislation or regulations. They would provide a safe harbour and might fall under what in Commonwealth countries is known as quasi-legislation. 
Yet, regardless of the approach in legislative technique chosen by national legislators towards copyright exceptions and limitations, TPMs and the legal protection of TPMs by way of so-called anti-circumvention provisions could prevent users from exercising their rights altogether. The following section addresses this delicate relationship between copyright exceptions and limitations on the one hand and TPMs and anti-circumvention provisions on the other.

The interplay between copyright exceptions and limitations and TPMs

a) TPMs and circumvention

TPMs are 'systems or applications which block access to and /or use of digital content on an absolute or conditional basis'. ${ }^{16}$ They are more euphemistically defined as 'technological method[s] intended to promote the authorised use of digital works'. ${ }^{17}$ As is evident from these definitions, TPMs control access to or the use of a work or both. They have been afforded some measure of protection by both international and domestic law as will be shown below. TPMs are sometimes part of Digital Rights Management (DRM) systems which are a much broader concept in that they may also incorporate rights management information (RMI) or end user licensing agreements (EULAs). ${ }^{18}$ Having made this distinction, this paper will focus only on TPMs.

TPMs are employed to protect both copyright protected works and unprotected (or public domain) works. In both instances the concern that rightful access to works may be hindered by TPMs arises. In the first case, this is because TPMs are unable to distinguish between infringing and non-infringing access to and uses of a copyright protected work ${ }^{19}$ and so can potentially block both types of access and/or use. As a result, fair dealing, for instance, and copyright infringement are treated in the same

\footnotetext{
16. N Garnett 'Presentation of the study entitled "Automated Rights Management Systems and Copyright limitations and Exceptions"', WIPO Standing Committee on Copyright and Related Rights: Seventeenth Session, Informative Sessions on Limitations and Exceptions, 3 November 2008, doc SCCR/17/WWW[111452] at 4 (hereafter N Garnett 'presentation of study'). 17. I R Kerr, A Maurushat and C S Tacit 'Technical protection measures: Tilting at copyright's windmill' (2002-2003) 34 Ottawa Law Review 7 at 13 (hereafter I R Kerr et al).

18. T Schonwetter, J de Beer, D Kawooya and A Prabhala 'Copyright and Education: Lessons on African Copyright and Access to Knowledge'(2009-10) 10 African Journal of Information and Communication 37.

19. I R Kerr et al supra note 16 at 31.
} 
way. In the second case, it is arguable that TPMs should not be applied to public domain works because this hinders access to them. Therefore in both cases, a person who lawfully has the right to access or use a work may find that they cannot exercise these rights due to the use of TPMs. In such cases the TPMs effectively extend rights-holders' copyright protection beyond the limits set by copyright law'. ${ }^{20}$

In a bid to access or use such protected works some people resort to circumvention, which is overcoming the TPMs by technological or other means to gain access to or use a work. ${ }^{21}$ As is to be expected, rights-holders take exception to circumvention of their TPMs. Further, such circumvention may be illegal. Clearly there is a tension between users and rights-holders that needs to be resolved. Copyright law has achieved a balance in the analogue world between users and rights-holders through its provision for exceptions and limitations as discussed in part 1 above. However, in the digital environment these tensions are revived by the use of TPMs ${ }^{22}$ and another solution has to be sought. The heart of the matter is how to reconcile copyright law and the legal protection of TPMs to ensure that this balance is maintained. ${ }^{23}$

The following discussion of TPMs and circumvention is premised on the basis that the technologies used are 'inherently neutral' because they may be used for both lawful and unlawful purposes. ${ }^{24}$ Rights-holders may use TPMs merely to secure their work without any intention to extend the scope of the rights granted to them by copyright law - or they may use TPMs with that very intention. Likewise, users may circumvent TPMs so as to exercise their lawful rights - or they could do so to gain unlawful access or use of a work. This paper addresses the concerns of persons with lawful rights to use or access works, particularly in the context of access to digitised material. This discussion begins with an analysis of the legal protection afforded to TPMs.

\footnotetext{
20. WIPO Study 'Automated Rights Management Systems and Copyright Limitations and Exceptions' by N Garnett, Doc SCCR/14/5 (hereafter N Garnett 'WIPO Study').

21. I R Kerr et al supra note 16 at 23.

22. These tensions have been analysed at length elsewhere. For example see R Burrell and A Coleman Copyright exceptions: the digital impact (2005) 67 et seq.

23. N Garnett 'presentation of study' supra note 15 at 3.

24 . Ibid at 3 .
} 


\section{b) Legal protection of TPMs}

Newer international treaties provide some protection against the circumvention of TPMs. Most importantly, Article 11 of the WCT provides as follows: ${ }^{25}$

Contracting Parties shall provide adequate legal protection and effective legal remedies against the circumvention of effective technological measures that are used by authors in connection with the exercise of their rights under this Treaty or the Berne Convention and that restrict acts, in respect of their works, which are not authorized by the authors concerned or permitted by law.

The WCT does not define TPMs. Member states are therefore at liberty to both interpret and implement the provisions in a manner they deem appropriate. The full import and meaning of Article 11 will not be discussed here as it has been discussed by other scholars elsewhere. ${ }^{26}$ However, it is important to emphasise that such protection is conditional and not all TPMs are protected. Only those TPMs that are effective and are used by copyright- holders against infringing acts are protected. ${ }^{27}$

In addition to this international protection, numerous jurisdictions have provided for legal protection of TPMs in their domestic legislation pursuant to their signature and ratification of the WCT $^{28}$ African countries that have ratified the WCT and WPPT include Ghana and Senegal. Morocco is in the process of ratification of both treaties following its conclusion of an FTA with the U.S. South Africa, Kenya, Egypt have also enacted anti-circumvention provisions although they have neither signed nor ratified the Internet treaties. This paper will comment briefly on South Africa and Morocco's provisions. These two countries have been selected for comment because they represent, in South Africa's case, an overly restrictive approach and, in Morocco's case, a more fairly balanced approach.

\footnotetext{
25. Article 18 of the WPPT makes similar provisions.

26. See for example N Garnett 'Wipo Study' supra note 19 at 11-12, C Visser 'Technological Protection Measures: South Africa goes overboard. Overbroad.' (2006) 7 SAJIC 54 at 56-57, I R Kerr et al supra note 16 at $34-36$. 27. I R Kerr et al supra note 16 at 35-36.

28. For example the US through the DMCA, the UK and Australia. See N Garnett 'WIPO Study' supra note 19 at 135 - 142, C Visser supra note 25 at $57-61$.
} 
Section 86 of South Africa's Electronic Communications and Transactions (ECT) Act 25 of 2002 exceeds the measures required by the WCT in that it is an absolute prohibition of both circumvention and trading in circumvention devices. ${ }^{29}$ As noted by Visser

'[i]t is incomprehensible that South Africa, a developing country, should opt for a system of protecting TPMs that is far more destructive of research and education than the systems adopted in the United States and Europe'. ${ }^{30}$

Under its FTA with the U.S., Morocco was required to implement anti-circumvention provisions in a more precise manner than required by the WCT and WPPT. Morocco's copyright legislation was accordingly amended in $2006^{31}$ and Article 65 of Morocco's copyright legislation now deals with anti-circumvention. However, article 65.1 provides that the anti-circumvention provisions are not applicable to non-profit libraries, archives, educational institutions and public broadcasters. Thus, to a meaningful extent, Morocco has preserved its copyright exceptions and limitations in the digital world by using a more fairly balanced approach with exceptions which benefit access to knowledge. This approach was possible because Morocco availed itself of the flexibility available from a combination of the WCCT/ WPPT and its FTA with the US.

c) Analysis and a possible solution

The legal protection of TPMs is essentially a third level of copyright protection. ${ }^{32}$ The first level is the copyright protection for the content itself and the second level is de facto protection by the TPMs. Unfortunately, by their very nature, TPMs are able to thwart the exercise of rights granted by exception and limitations. Herein lies the tension, referred to above. In the context of access to learning materials this is

\footnotetext{
29. C Visser supra note 25 at 62.

30. Ibid.

31. Morocco Copyright Act, Law No. 2-00 on Copyright and Related Rights (Dahir No. 1-00-20 of

15 February 2000 (9 kaada 1420)) was amended by law number 34-05 promulgated by the 1-05192 dahir of 14 February 2006.

32. B Hugenholtz 'Code as code, or the end of intellectual property as we know it' (1999) 6 (3) Maastricht Journal of European and Comparative Law 308, at 8, available at http://www.ivir.nl/publications/hugenholtz/maastricht.doc [accessed on 21 January 2010].
} 
particularly problematic. The very technology one hoped would facilitate increased access is now being used to hamper access. From this perspective, it appears that anti-circumvention provisions are counter-productive. ${ }^{33}$ They potentially disrupt the delicate balance between the rights of copyright-holders and users in the realm of copyright law. As a result, in order to secure access and use of works, users are often compelled to accept restrictive licences that grant them rights that already fall within the scope of an accepted copyright exception and limitation. ${ }^{34}$ In such circumstances TPMs (or computer code) conflict with and effectively render useless existing and well-established copyright exceptions and limitations such as fair dealing and fair use. This phenomenon has been described with the catchy phrase "code as law". 35 As shown in the first part of this paper, copyright exceptions and limitations are, however, crucial for achieving a fair copyright balance and for accomplishing as many of the different purposes of copyright law as possible.

One way to reconcile the problematic relationship is to treat copyright exceptions and limitations as permitting the circumvention of TPMs. In other words, copyright exceptions and limitations would also prevail against anti-circumvention provisions. Under such an approach, it would be possible to address concerns about the inability of TPMs to distinguish between certain permitted uses, such as fair use or fair dealing, and copyright infringement. Currently, however, copyright exceptions and defences are usually not treated as defences against anti-circumvention claims. Section 1201(c)(1) of the U.S. Digital Millennium Copyright Act (DMCA), for instance, specifically provides that the anti-circumvention regime does not affect rights, remedies, limitations or defences to copyright infringement, including fair use. Hence, it appears that a copyright exception like fair use would be a valid defence to anti-circumvention claims. However, the provision has been interpreted differently

\footnotetext{
${ }^{33}$ Hugenholtz has critically noted that the potential of anti-circumvention provisions to severely hamper the dissemination of knowledge and culture within a society strongly militates against such provisions. This is because the promotion of knowledge and culture is one of the most important (utilitarian) copyright rationales (B Hugenholtz 'Copyright, contract and code: what will remain of the public domain' (2000) 26 Brooklyn Journal of International Law 77 at 86). 34. R McGreal 'Stealing the Goose: Copyright and Learning'(2004) 5 International Review of Research in Open and Distance Learning, at 4, available at http://www.irrodl.org/index.php/irrodl/article/view/205/819 [accessed on 21 January 2010]. 35. See, for instance, L Lessig's book title: Code and Other Laws of Cyberspace.
} 
by the courts. In Universal City Studios, Inc. v Corley, the US Court of Appeals held that the provision 'simply clarifies that the DMCA targets the circumvention of digital walls guarding copyrighted material (and trafficking in circumvention tools), but does not concern itself with the use of those materials after circumvention has occurred. Subsection 1201(c)(1) ensures that the DMCA is not read to prohibit the "fair use" of information just because that information was obtained in a manner made illegal by the $\mathrm{DMCA}^{\prime}{ }^{36}$

Having said this, the proposed amendments to the Indian Copyright Act may present a possible solution. The proposed bill has not been officially published although some sectors of the open source community have cited sections of the bill in their advocacy material. ${ }^{37}$ So far the Ministry of Human Resource Development has announced that cabinet approval has been granted for the introduction of the bill to parliament. ${ }^{38}$ In that announcement the ministry has stressed that it intends to temper the introduction of anti-circumvention provisions by

maintaining an appropriate balance between the interests of the right holders on the one hand and of technology innovators, researchers and educational institutions on the other.

The relevant section 65A (1) of the proposed bill reads as follows:

Any person who circumvents an effective technological measure applied for the purpose of protecting any of the rights conferred by this Act, with the intention of infringing such rights, shall be punishable with imprisonment which may extend to two years and shall also be liable to fine. (emphasis added)

\footnotetext{
36. 273 F.3d 429, 443 (2d Cir. 2001).

37. See FOSS Community India 'Anti-DRM-Campaign/Proposed-Amendments' < http://fci.wikia.com/wiki/Anti-DRM-Campaign/Proposed-Amendments $>$ (last accessed 21 January 2010).

38. Ministry of Human Resource Development 'Press Release on Amendment to the Copyright Act, 1957' 24 December 2009 < http://pib.nic.in/release/rel_print_page1.asp?relid=56444 > (last accessed 21 January 2010). For a commentary on the proposed changes see A R Chowdhury "The future of copyright in India' Journal of Intellectual Property Law \& Practice 2008 3(2):102-114.
} 
Under Indian law, an unauthorised use of copyright protected material does not qualify as copyright infringement if the user can succesfully invoke a copyright exception and limitation. It is suggested here that, consequently, a person who circumvents TPMs in order to merely make use of an accepted copyright exception and limitation would never have the 'intention of infringing' the rights-holders copyrights.

\section{Summary and conclusion}

Recent South African research projects, including the ACA2K research project and the Open Review of the South African Copyright Act, confirmed that copyright exceptions and limitations are crucial balancing tools for enabling access to important (digital) knowledge materials. Based on these findings, this paper strived to advance the quality of discussions about copyright exceptions and limitations by providing essential legal background information on the topic. In addition, the above discussion illustrated the tensions between rights-holders and users caused by anticircumvention provisions which exclude the exercise of copyright exceptions and limitations in a development framework. The core issue is that TPMs make it impossible to access and/or use copyright-protected material for purposes which are usually exempt under long-established national copyright exceptions and limitations. In addition, this raises developmental and human rights concerns.

The solution proposed here is to resolve this tension by allowing users to circumvent TPMs in the exercise of their rights under copyright exceptions and limitations. In effect, this would be transferring the current status quo in the analogue world to its digital equivalent. For African countries, it is crucial that users, particularly learners, can access knowledge material to further education and achieve economic, social and political development goals. The authors of this paper prefer an express legislative statement that allows the circumvention of TPMs in the exercise of copyright exceptions and limitations. Alternatively, however, national lawmakers could follow Morocco's example of determining that anti-circumvention provisions are not applicable to selected institutions and/ or user groups, or adopt the 
approach proposed by the Indian legislator which, in our understanding, stipulates that a person who circumvents TPMs in order to make use of an accepted copyright exception and limitation does not violate the country's anti-circumvention provisions due to lack of intention to commit copyright infringement.

After all, safeguarding an optimal balance of interest, for the benefit of development, in the copyright arena in times of rapid technological change is a continuous struggle. It requires the combined efforts of both legal specialist and ICTS professionals, and we should not shy away from considering the experiences and legislative mistakes of other countries in this field. New paradigms such as Open Innovation, which, among other things, more fundamentally question the utility of broad intellectual property protection, make a socially responsible and informed use of technological means to protect IP all the more important. 


\section{$\underline{\text { References }}$}

\section{Legislation, FTAs and Cases}

Agreement on trade-related aspects of intellectual property rights including trade in counterfeit goods (TRIPs).

Australia-U.S. Free Trade Agreement (AUSFTA).

Australian Copyright Act.

Berne Convention for the protection of literary and artistic works .

Chinese Copyright Act.

EC Database Directive (96/9/EC).

EC Rental Right Directive (2006/115/EC).

EU Computer Programs Directive (91/250/EEC).

EU Copyright Directive (2001/29/EC).

French IPC.

Greek Copyright Act.

Italian Copyright Statute.

Moroccan Copyright Act.

North American Free Trade Agreement (NAFTA).

Portuguese Act on Copyright.

South African Copyright Act.

Spanish Copyright Act.

UK Copyrights, Designs and Patents Act (CDPA).

Universal City Studios, Inc. v Corley 273 F.3d 429, 443 (2d Cir. 2001).

U.S. Digital Millennium Copyright Act (DMCA).

U.S.-Singapore Free Trade Agreement.

WIPO Copyright Treaty.

WIPO Performances and Phonograms Treaty.

\section{$\underline{\text { Secondary literature }}$}

Burrell, Robert and Coleman, Allison Copyright exceptions: the digital impact (2005) Cambridge University Press, U.K. 
Chowdhury, Ayan Roy 'The future of copyright in India' (2008) 3 Journal of Intellectual Property Law \& Practice 102.

Drahos, Peter and Mayne, Ruth Global Intellectual Property Rights: Knowledge, Access and Development.(2002) Palgrave Macmillan, U.K.

FOSS Community India 'Anti-DRM-Campaign/Proposed-Amendments', available at http://fci.wikia.com/wiki/Anti-DRM-Campaign/Proposed-Amendments

Garnett, Nic 'Presentation of the study entitled "Automated Rights Management Systems and Copyright limitations and exceptions"', WIPO Standing Committee on Copyright and Related Rights: Seventeenth Session, Informative Sessions on Limitations and Exceptions, 3 November 2008, doc SCCR/17/WWW[111452].

Gervais, Daniel J 'Towards a new core international copyright norm: The reverse three-step test' (2005) 9 Marquette Intellectual Property Law Review 1.

Hugenholtz, Bernt 'Code as code, or the end of intellectual property as we know it' (1999) 6 (3) Maastricht Journal of European and Comparative Law 308, available at http://www.ivir.nl/publications/hugenholtz/maastricht.doc

Hugenholtz, Bernt 'Copyright, contract and code: what will remain of the public domain' (2000) 26 Brooklyn Journal of International Law 77.

Kerr, Ian R; Maurushat, Alana and Tacit, Christian S 'Technical protection measures: Tilting at copyright's windmill' (2002-2003) 34 Ottawa Law Review 7.

Laddie, Hugh et al The modern law of copyright and designs [3ed] (2000) Butterworths, U.K.

Lessig, Lawrence Code and Other Laws of Cyberspace (2000) Basic Books, U.S.

McGreal, Rory 'Stealing the Goose: Copyright and Learning' (2004) 5 International Review of

Research in Open and Distance Learning, available at http://www.irrodl.org/index.php/irrodl/article/view/205/819

Ministry of Human Resource Development 'Press Release on Amendment to the Copyright Act, 1957' 24 December 2009, available at http://pib.nic.in/release/rel print page1.asp?relid=56444

Rens, Andrew et al 'Report on the South African Open Copyright Review' (2008), available at http://www.shuttleworthfoundation.org/our-work/intellectual-property-

rights/projects/report-sa-copyright-act

Schonwetter, Tobias; de Beer, Jeremy; Kawooya, Dick and Prabhala, Achal 'Copyright and Education: Lessons on African Copyright and Access to Knowledge' (2009-10) 10 African Journal of Information and Communication 37.

Visser, Coenraad 'Technological Protection Measures: South Africa goes overboard. Overbroad.' (2006) 7 Southern African Journal of Information and Communication 54.

WIPO Study 'Automated Rights Management Systems and Copyright Limitations and Exceptions' (by N Garnett) Doc SCCR/14/5. 


\section{Search - Publisher copyright policies \& self- archiving}

One journal found when searched for: info

Journal: info (ISSN: 1463-6697)

RoMEO: This is a RoMEO green journal

Paid OA: A paid open access option is available for this journal.

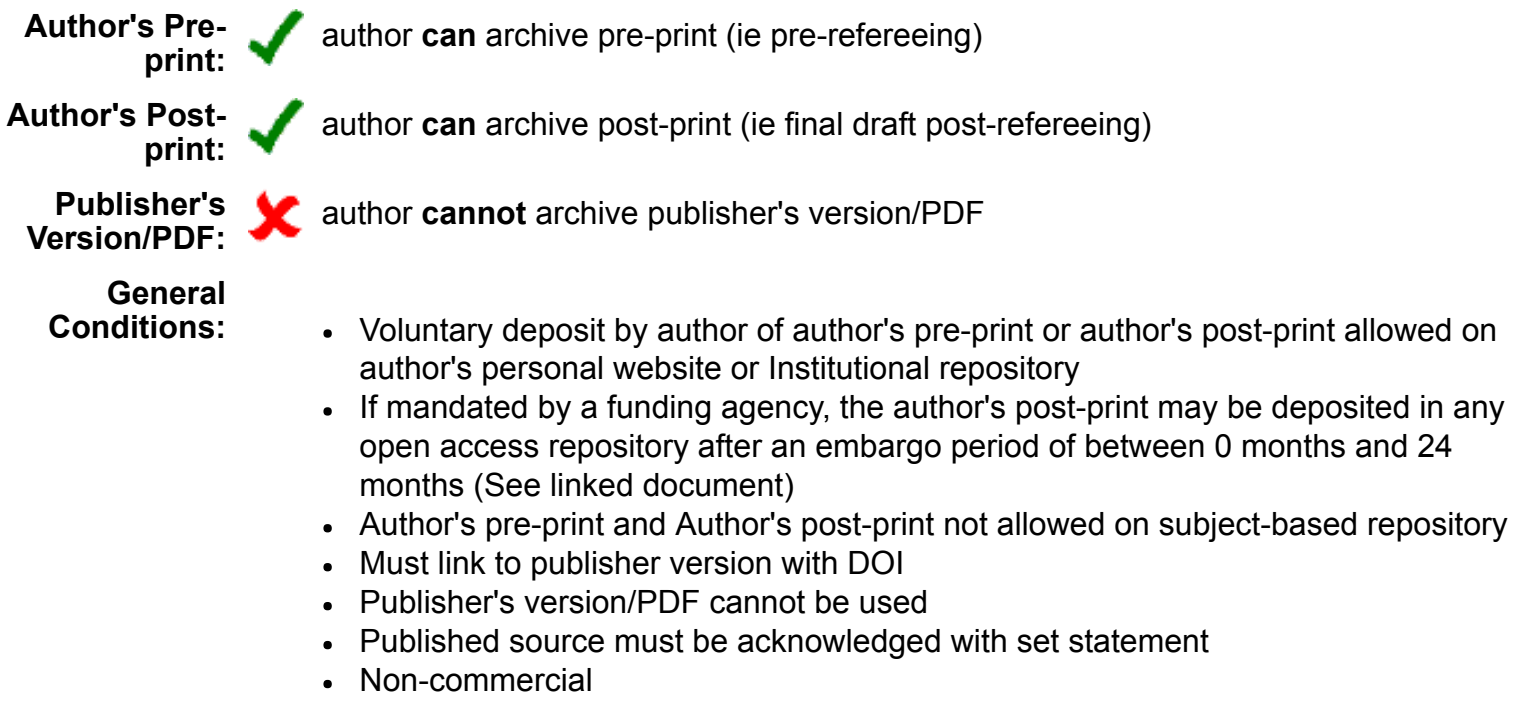

Mandated OA: (Awaiting information)

Paid Open Open Access for authors

Access:

Notes:

- Publisher last contacted on 02/04/2013

Copyright: Emerald and Open Access - Emerald Author rights - Embargo List for authors submitting to REF or who are mandated to deposit but do not have funds to pay for Paid OA (pdf)

Updated: 24-Feb-2016 - Suggest an update for this record

Link to this http://www.sherpa.ac.uk/romeo/issn/1463-6697/ page:

Published by: Emerald - Green Policies in ROMEO

This summary is for the journal's default policies, and changes or exceptions can often be negotiated by authors.

All information is correct to the best of our knowledge but should not be relied upon for legal advice. 
Yellow Can archive pre-print (ie pre-refereeing)

White Archiving not formally supported

More on colours and restrictions

or $\quad$ View all publishers

Use this site to find a summary of permissions that are normally given as part of each publisher's copyright transfer agreement.

The RoMEO Journals database is supplemented with information kindly provided by:

- the British Library's Zetoc service hosted by MIMAS,

- the Directory of Open Access Journals (DOAJ) managed by Infrastructure Services for Open

Access,

- the Entrez journal list hosted by the NCBI. 